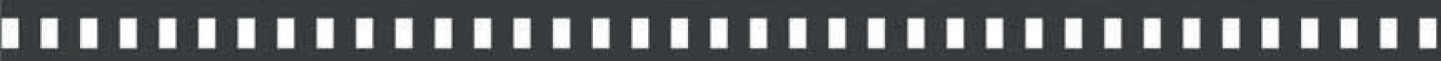

\section{A Revista Illustrada educando para a República}

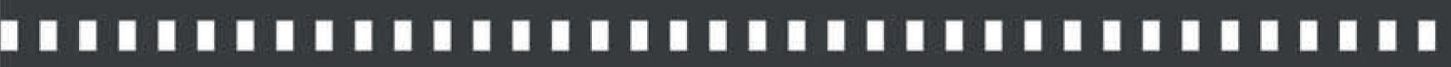

Thiago Vasconcellos Modenesi

Edilson Fernandes De Souza

Vilde Gomes De Menezes

Artigo recebido em: 21/09/2015

Artigo aprovado em: 08/05/2016 


\title{
A Revista Illustrada educando para a República
}

\author{
The Journal Illustrada educating for Republic
}

* Thiago Vasconcellos Modenesi, ** Edilson Fernandes De Souza, $\mathrm{e}^{\text {**** Vilde Gomes De Menezes }}$

\begin{abstract}
Resumo: Este artigo tem como principal objetivo identificar as possibilidades educacionais contidas em materiais da imprensa nos primeiros anos da República do Brasil, a partir da ascensão do Partido Conservador, com o fim do Império e do regime escravagista. A análise parte da hipótese de que a Revista Illustrada colaborou na maneira de historiar os fatos à população não letrada, na criação de uma espécie de método de transmitir os acontecimentos com um novo olhar, a partir da mudança dos hábitos e dos referenciais de higiene corporal, de boa educação e de civilidade.
\end{abstract}

Palavras-chave: Educação; Histórias em quadrinhos; República; Civilidade

\begin{abstract}
This article aims to identify the educational possibilities contained in press materials in the early years of the Republic of Brazil, from the rise of the Conservative Party, with the end of the Empire and slave regime. Our analysis starts from the hypothesis that the Revista Illustrada collaborated in the way of historicizing the facts to non-literate population, creating a kind of method of transmitting the events with a new look, from the change of habits and of body care benchmarks, good manners and civility.
\end{abstract}

Keywords: Education; Comic books; Republic; Civility

\footnotetext{
* Graduado em história, especialista em ensino de história, mestre e doutor em educação, professor adjunto da faculdade dos guararapes desde 2013.

** Professor do Núcleo Teoria e História do Programa de Pós-graduação em Educação da Universidade Federal de Pernambuco. Pós-Doutor em Sociologia pela Universidade do Porto-Portugal. Bolsista de Produtividade do CNPQ. *** Professor do Núcleo Teoria e História do Programa de Pós-graduação em Educação da Universidade Federal de Pernambuco. Mestre em Ciência Política pela Universidade Federal de Pernambuco. Doutro em Ciências do Desporto pela Universidade do Porto-Portugal. Bolsista de Produtividade do CNPQ.
} 


\section{Introdução}

Discutimos neste artigo a importância da imprensa como instrumento político na consolidação de novos hábitos e costumes e na apresentação de um modelo de civilidade para os indivíduos que viveram as paisagens históricas do Império e da República brasileira. A análise sustenta a ideia de que os órgãos de impressa ocupavam uma considerável faixa de interesse social no debate dos principais problemas do Brasil.

Entre os órgãos de imprensa, as revistas, e especialmente as imagens nelas contidas, serviram de instrumento político com o objetivo de provocar uma experiência educativa para alterar o olhar sobre o sistema escravocrata, para além dos que sabiam ler nessa configuração monárquica.

Contudo, para efeito deste artigo, tomamos como objeto a Revista Illustrada pela sua importância na contestação do Império. A postura crítica assumida pela Revista, nesse período, ocupou um espaço de tempo considerável na imprensa. Sua longevidade chega até meados da República, momento em que passou a ter uma postura de apoio a essa nova forma política organizativa do Brasil, tornando-se, praticamente, um panfleto republicano, segundo Maringoni (2011).

Muitas ilustrações foram publicadas com o enfoque dos novos costumes e de questões ligadas à escola da República entre a edição de $n^{\circ} 569$, do ano de 1889 , e a última edição, de $n^{\circ} 739$, do ano de 1898. No entanto, focamos a análise nas capas, contracapas e páginas centrais, especialmente as que citam a escola, a educação, os aspectos de civilidade e progresso, presentes no discurso da Revista sobre o regime republicano, em contraposição ao Império. Essas fontes podem ser facilmente encontradas na Hemeroteca Digital Brasileira, baseada na Fundação Biblioteca Nacional, onde podemos acessar todas as edições entre 1876 a 1898. O resguardo dessa documentação revela a preocupação com a memória de um cotidiano muito importante para história brasileira. 
Enquanto objeto de investigação, a Revista Illustrada é uma evidência da possibilidade de questionamentos e rejeição de um sistema que necessitava ser extinto, por isso os esforços do editor para provocar a reação em letrados e não letrados, unindo texto e ilustração para melhor comunicar o desejo de mudança da realidade. Dessa forma, na medida do possível, tentamos resguardar a grafia dos textos extraídos do periódico para dar mais força à representação de um cotidiano tensionado entre monarquia, atraso, progresso, educação e civilidade.

\section{Império, imprensa e República}

É inegável o papel da imprensa no período que vai do Segundo Reinado até o início da República. Autores como Costa (2012), que trata da história das publicações em nosso país, e Tarde (2005), que discute a importância da opinião e do discurso vinculado à relevância da imprensa nesse processo, enfatizam a circulação de ideias a partir de textos e imagens.

Costa (2012) faz importantes considerações sobre a influência da imprensa no cotidiano que antecede o ano de 1889, ao mesmo tempo em que chama a atenção para o fato de que o que era veiculado permitia uma construção de identidade social a partir das publicações. Assim, os periódicos, e especialmente as revistas, diz o autor, sempre serviram de espelho em que a sociedade se via e se reconhecia em cada cidadão.

A imprensa, em todos os tempos, foi um grande instrumento de repercussão das conversas diárias dos que lutavam pela construção da sociedade brasileira. As publicações impulsionavam os debates sobre o modelo de governo que se pretendia para a organização e estrutura social. "Em cada década, as revistas abriram espaço e reproduziram os temas que ocupavam as rodas de cidadãos empenhados em construir um país" (COSTA, 2012, p. 438). Sua atuação dava visibilidade aos grandes temas da sociedade, bradando 
a singularidade da nação que se almejava, mais comprometida com os problemas da população.

Como era de se esperar, a imprensa participava de todos os meandros da vida social. Fosse com a chegada das mulheres nas redações, nos momentos de crise diplomática entre Brasil e Inglaterra, ou em momentos de guerra. Assim, em várias situações "a imprensa foi um dos elementos formadores da ideia de nação que se criava" (COSTA, 2012, p. 439).

É a partir das revistas da imprensa brasileira que temos um importante apoio ao esforço de edificação da brasilidade, da constituição do Brasil enquanto nação, naquele contexto de fim do século XIX e início do século XX. "Foi pelas páginas das publicações que se debateram problemas nacionais, se fixaram os padrões de gosto e certo jeito de ser que traduz a brasilidade" (COSTA, 2012, p. 440).

$\mathrm{O}$ autor destaca, ainda, que foi através das páginas dos jornais e revistas que o país se repensou enquanto nação, inclusive, possibilitando a unidade nacional através da escrita e consolidação da grafia. $\mathrm{O}$ espelho que refletia a circulação das ideias também possibilitou a consolidação de um corpo técnico e a sua continuidade no ofício de formar as consciências críticas.

Entretanto, a construção da brasilidade chega a um novo patamar com a proclamação da República. A necessidade de afirmar a nação, seus hábitos e costumes torna-se mais e mais estratégica para legitimar um governo que havia ascendido com a necessidade de buscar apoio e reconhecimento popular e dos setores diversos da sociedade brasileira. Aqui começa a edificação de um novo discurso com vistas à garantia da sustentação do novo regime em meio a um cenário político novo e conturbado, bem descrito por Maringoni:

Assim, quem proclama a República não são as frações de classe mais profundamente interessadas nela, mas um setor que tinha atritos pontuais com o regime. Essa contradição gera uma década de instabilidade e de intensa luta política, 
até a oligarquia cafeeira assumir a plena hegemonia do processo, a partir de 1898, com a chegada do paulista Campos Salles ao palácio. Ao invés de fechar um ciclo de disputas, o 15 de novembro abre um novo período de confrontos, choques, conspirações, rebeliões e debates, mostrando que a unanimidade acerca da nova situação estava longe de acontecer. (MARINGONI, 2011, p. 157)

Já Tarde (2005) faz um profundo debate sobre a importância da imprensa na formação de um discurso, em particular de um novo discurso. $\mathrm{O}$ autor ressalta a importância da opinião, em sua obra $\mathrm{A}$ Opinião e as Massas, destacando sua restrição a pequenos estratos sociais, na maioria das vezes sem diálogo entre si. O aumento exponencial da opinião e a sua importância vieram com o advento da imprensa, se tornando nacional e até internacional: "A opinião está para o público, nos tempos modernos, assim como a alma está para o corpo, e o estudo de um nos conduz naturalmente ao outro" (TARDE, 2005, p. 59).

As reflexões do autor são fundamentais para a compreensão do nosso objeto de estudo, especialmente para o debate acerca da disputa do velho e do novo contido na luta de ideias, na construção do novo discurso, entre o Império que se foi e a República que chega. A justa análise de Tarde (2005) nos mostra que as opiniões não estão isentas do peso das tradições que as antecederam secularmente e a razão que marca as elites, mesmo que não misturadas a parcelas mais largas das correntes populares, ainda assim buscando as formas de dirigi-las.

Para Tarde (2005), razão e tradição são componentes fundamentais na formulação de um discurso do espírito de uma sociedade. Pensar o novo e, sobretudo, romper a tradição, cujo discurso terá de ser forte o suficiente para construir outra realidade. Razão é o discurso do novo, do que se pretende reafirmar; e tradição é o discurso da herança dos mortos. Assim, razão e tradição estão sempre na disputa de fronteiras. 
Nesse sentido, o debate acerca da construção de uma nova opinião precisa, via de regra, levar em consideração a tradição construída anteriormente somada à razão do contexto, e esse aspecto é defendido pelo autor ao refletir sobre a importância da opinião.

Bem antes de ter uma opinião geral e sentida como tal, os indivíduos que compõem uma nação têm consciência de possuir uma tradição comum e submetem-se de bom grado às decisões de uma razão julgada superior. Assim, desses três ramos do espírito público, o último a se desenvolver, mas também o mais apto a crescer a partir de um certo momento, é a opinião; e ela cresce à custa dos outros dois. Contra seus assaltos intermitentes não há instituição nacional que resista; diante de suas ameaças ou intimações não há razão individual que não trema ou não balbucie. Qual dessas duas rivais é mais prejudicada pela opinião? Isso depende de quem a dirige. Quando estes fazem parte da elite pensante, acontece-lhes às vezes erguer a opinião como um aríete para derrubar a muralha tradicional e, destruindo-a, ampliá-la, o que não deixa de comportar perigos (TARDE, 2005, p. 60, 61).

Para nós, a opinião impressa nas páginas da Revista Illustrada estava no campo que abrange o aríete de Tarde (2005), que busca destruir a muralha da tradição e erguer uma nova, como novos costumes, procedimentos, hábitos e outros elementos que compõem esse momento republicano do Brasil.

Tarde (2005), ressalta a importância da imprensa em sua obra ao tratar do valor das coisas, de maneira que "a conversação em todos os tempos e a principal fonte atual de conversação, a imprensa, são os grandes fatores de opinião, sem contar evidentemente a tradição e a razão, que não deixam jamais de participar e imprimir suas marcas" (TARDE, 2005, p. 62). Assim, o autor faz a defesa do papel da imprensa na edificação dessa consciência mais afinada entre 
setores mais largos da sociedade quando debate a transformação da opinião individual na opinião social.

A busca de uma opinião unificadora e unificada, reconhecida por parcelas mais amplas da sociedade, se materializa no fortalecimento da imprensa como instrumento de maior alcance e capilaridade para transmitir um determinado discurso, a exemplo do que a Revista Illustrada fez nos primeiros anos da República, no aspecto de estar em sintonia com o discurso do sistema, mas não na circulação que despencava ao passar dos anos.

Por outro lado, não há como negarmos que, no Brasil, as opiniões sempre existiram, inclusive as nacionais e as internacionais, mas a maneira com a qual a sociedade as trata e com elas se relaciona muda profundamente com o advento da imprensa, influenciando a formação do espírito público. Segundo Tarde (2005), a digressão na história do país nos faz entender o quanto era hegemônica a opinião local. Embora também seja possível o entendimento de que havia a superposição das opiniões, na perspectiva das províncias, das cidades etc.

Nesse sentido, é fácil percebermos o papel da imprensa na circulação das ideias republicanas, bem como o fomento à "institucionalização" das opiniões contrárias a respeito da situação insustentável da sociedade escravocrata, a exemplo das publicações da Revista Illustrada.

\section{A Revista Illustrada educando para República}

Fundada pelo italiano Angelo Agostini em primeiro de janeiro de 1876, a Revista Illustrada foi uma publicação que teve, entre os veículos de imprensa, grande impacto no Segundo Reinado do Império de nosso país. Sua relevância é comprovada pela circulação muito maior do que a média dos demais diários e semanários publicados na capital federal. 
$\mathrm{Na}$ capa da segunda edição, Angelo Agostini faz um agradecimento pelos elogios recebidos dos demais periódicos. E, de forma amistosa, o editor da Revista Illustrada chama a atenção para a forma com que foi recebido no cenário jornalístico do Império do Brasil. Aliás, esses elogios passam a ser constantes, na medida em que o italiano avança com suas críticas aos vários problemas enfrentados pela população, sejam questões econômicas, a inércia do Império ou a exploração da mão de obra escrava.

É importante ressaltar que a Revista tentava retratar o cotidiano do Império como um ambiente da indiferença e do obscurantismo, no qual imagem e texto confluíam para comunicar a situação desumana com que eram tratados os escravos. Dessa forma, letrados e não letrados tinham acesso à mesma ideia pretendida pelas edições do semanário, que era a de provocar reação ao regime escravista e fazer emergir a república, como representação do progresso e da civilidade. 


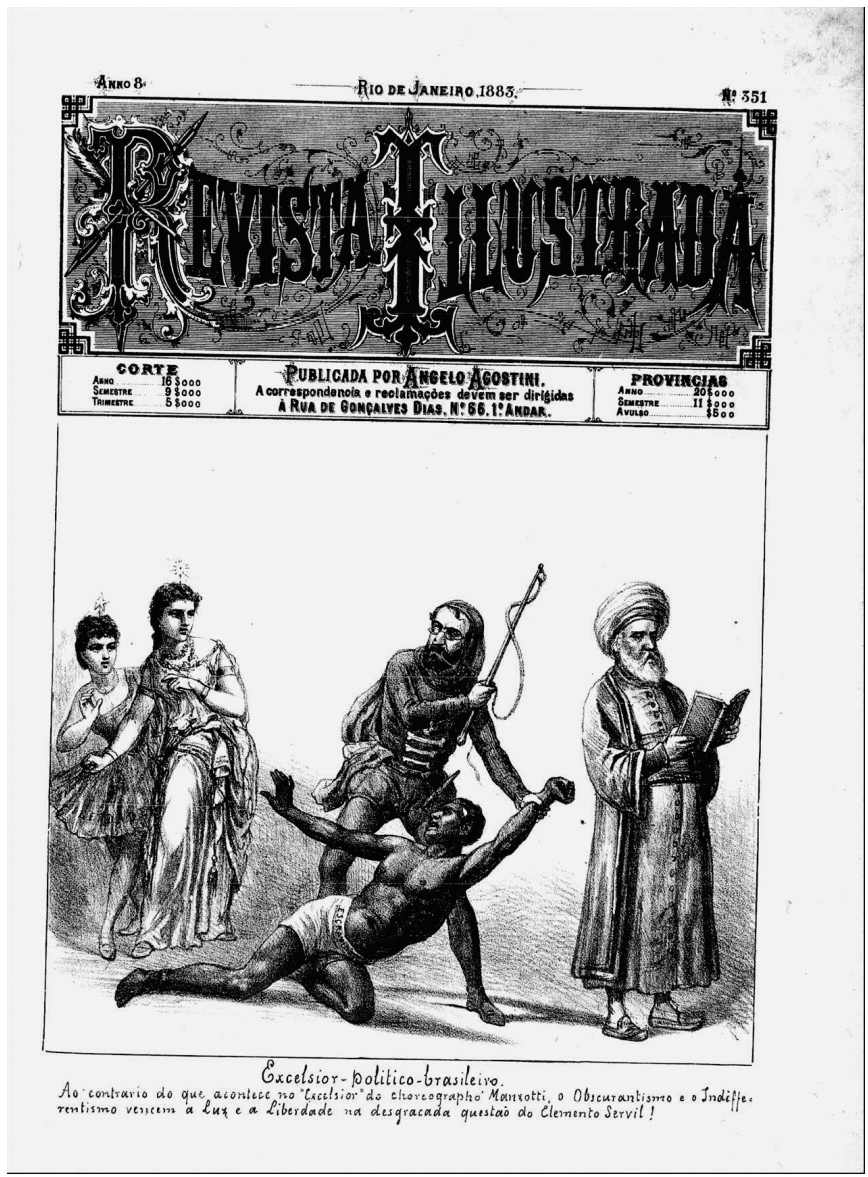

Capa da Revista Illustrada, edição nº 351 de 1883

O que se lê logo abaixo da ilustração é o que se segue: "Excelsior-politico-brasileiro. Ao contrario do que acontece no "Excelsior" do choreographo Manzzoti, o Obscurantismo e o Indifferentismo vencem a Luz e a Liberdade na desgracada questão do Elemento Servil!"” (Revista Illustrada, edição no, 351 de 1883)

É fácil observar que a Revista tornou-se parte do movimento pró-abolição, e logo foi homenageada pela Sociedade Abolicionista do Rio de Janeiro e por figuras importantes do movimento 
antiescravagista e republicano, a exemplo de Joaquim Nabuco. A opção da defesa pelo fim da escravidão tinha um claro vínculo com a contestação do regime, e não simplesmente uma postura humanista e solidária para com os escravizados.

Concretamente, a situação do escravismo no Brasil já estava insustentável, e a Revista colaborava na ideia da impossibilidade de o sistema permanecer vigorando, como veremos na ilustração abaixo, onde alguns se esforçam para conter a abolição.

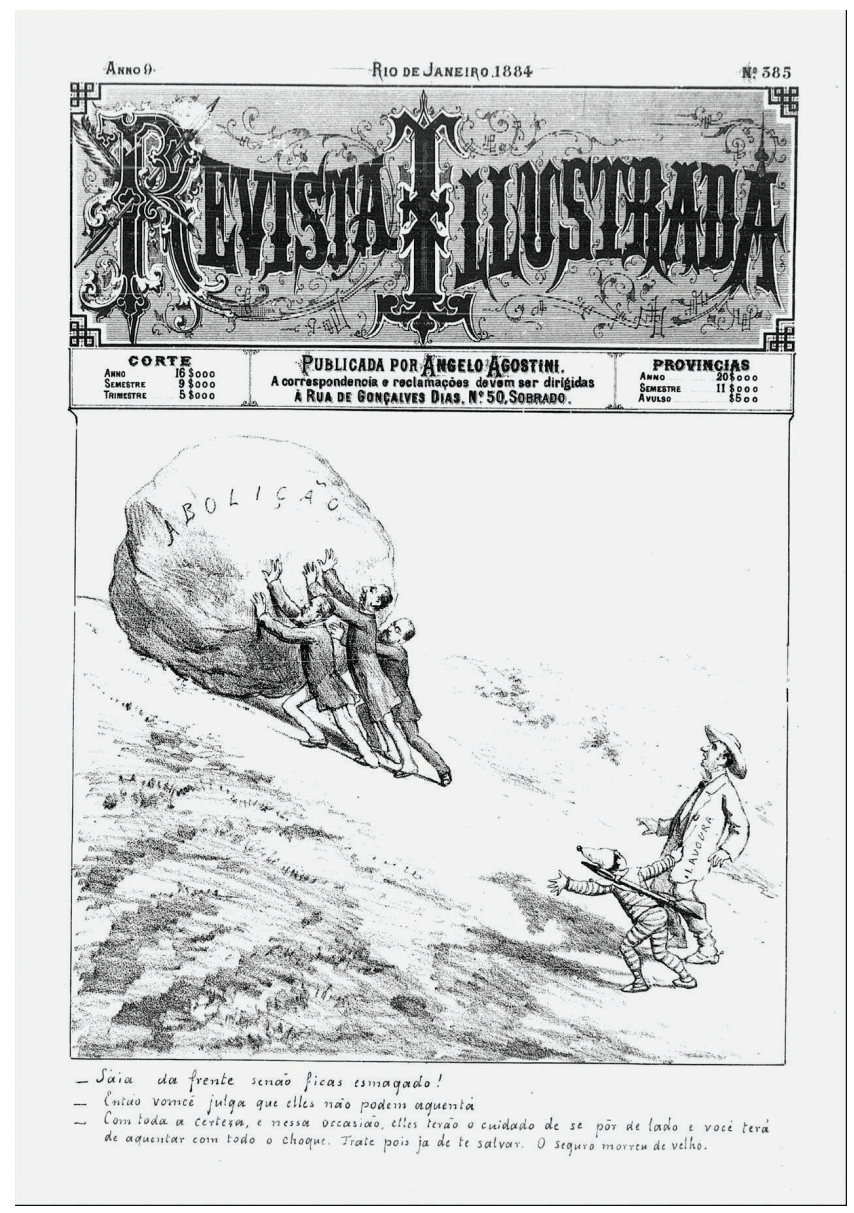

Capa da Revista Illustrada, edição no 385, de 1884 
O texto abaixo da ilustração é o seguinte:

- Sai da frente senão ficas esmagado!

- Então vomcê julga que elles não podem aguentá

- Com toda certeza, e nessa ocasião, elles terão o

cuidado de se por de lado e você terá de aguentar com todo o choque. Trate pois já de te salvar. O seguro morreu de velho (Revista Illustrada, edição no 385 , de 1884)

Como podemos observar, o esforço do editor é unir ilustração e texto para dar a ideia de inevitabilidade ao novo sistema. Naquela época era pequena a quantidade de alfabetizados e se pretendia estabelecer um diálogo entre o público da Revista e os desenhos, estes tendo um caráter subjetivo para educar. A observação dos desenhos também era uma leitura das imagens que funcionavam de maneira parecida com as palavras para os que sabiam ler. Assim, podemos comparar textos e imagens para a construção de sentido.

Tal afirmação se apoia nas teorias que compreendem o ser humano como uma criatura imagética, que dialoga e raciocina fundamentalmente a partir de imagens, inclusive quando pensamos em algo o fazemos a partir delas e não das letras e dos sons. Esta construção nos permite articular os dois hemisférios do cérebro, como nos explica Gazy Andraus (2006) tanto em sua pesquisa de doutorado como em publicações posteriores em que descreve e se apoia nas potencialidades desse raciocínio:

Assim, de certa maneira, as HQs representam uma materialização a partir de uma proeminência mental que parte do hemisfério direito cerebral (o criativo), o qual busca uma interação com o hemisfério esquerdo (que explica e organiza as ideias inovadoras), em que ambos se conectam à porção central reptiliana (responsável pelo pragmatismo) confluindo numa conjunção triádica necessária a um melhor funcionamento cerebral 
e mental, de acordo com a teoria de De Gregori (1999). Para este autor, a utilização proporcional de três vias traria um melhor equilíbrio a vida humana, já que ocorre um mal uso desproporcionado dos hemisférios. (ANDRAUS, 2006, p. 37).

Mais adiante em sua tese o autor nos explica que as histórias em quadrinhos cumprem uma função diferente dos textos lineares e fortalece a importância das imagens para nós, leitores: “[...] a leitura de imagens nas histórias em quadrinhos (ou dos ideogramas chineses) funciona de maneira distinta na mente humana, de uma leitura estrita dos fonemas e dos textos lineares cartesianos" (ANDRAUS, 2006, p. 37-38).

Outro autor que valoriza as imagens em suas reflexões, e os quadrinhos em particular, é Srbek (2014). Em sua obra Um Mundo em Quadrinhos, o autor discute a importância da ilustração junto ao texto para firmar uma ideia e dar sentido ao leitor.

Todavia, é importante lembrarmos que, numa sociedade cuja maior parte da população não sabia ler, a comunicação através de imagens tinha um papel fundamental, bastante explorado pelas instituições de poder (muito da comunicação entre a Igreja medieval e seus fiéis, por exemplo, fez-se através de vitrais, esculturas, pinturas, etc.). Considerando-se que a técnica de xilogravura já era difundida no final da Idade Média, o desenvolvimento da impressão de textos também incentivou o aperfeiçoamento das técnicas de impressão de imagens. Veiculadas como ilustrações em livros ou na forma de folhetos, as gravuras em madeira ou metal disseminaram-se amplamente a partir do século XVI, tendo grande importância no intercâmbio de ideias e tornando-se potenciais veículos para propagação de doutrinas (fato também explorado pelas autoridades leigas e religiosas) (SRBEK, 2014, p. 13). 
Essas reflexões do autor são fundamentais para a nossa compreensão acerca do que Angelo Agostini pretendia com suas ilustrações. E, embora sendo um dos grandes contestadores do regime, nos últimos anos do Império, o principal editor e colaborador da Revista Illustrada deixa o país. Na sequência ocorrem várias mudanças, passamos a viver em uma nação sem escravidão e republicana e altera-se a circulação da revista, com a queda nas vendas e o aumento dos preços, passando a atender um público mais elitizado, parte da elite republicana que surgia.

Aqui é importante refletirmos sobre as razões que levaram à queda de Dom Pedro II e, consequentemente, ao fim do Segundo Reinado do Império do Brasil. As razões são variadas, algumas estando entrelaçadas e outras não, além da superestimação que a abolição teve nesse processo: embora não se negue aqui sua importância, não foi o único vetor, e nem o mais importante isoladamente, que levou ao fim do regime imperial e à proclamação da República em solo brasileiro.

Autores como Fausto (2014) destacam dois setores que impulsionaram o fim da monarquia no Brasil. Ele considera que o Exército, praticamente, iniciou os episódios do dia 15 de novembro, e parte da burguesia cafeeira de São Paulo, por garantir uma base social estável, diferente da população urbana do Rio de Janeiro. $\mathrm{O}$ autor ainda faz referência aos aspectos naturais, como a doença do Imperador que, acometido de diabetes, foi obrigado a se afastar desse debate político.

Enquanto herdeiro do trono e detentor de prestígio pessoal, D. Pedro II absorvia as queixas do Exército, através de seus oficiais, que viviam em permanente confronto com parte da elite do Império. Para Fausto (2014), com menos peso, a Igreja também contribuiu para o desgaste da monarquia, e sua queda se deve mesmo às disputas existentes entre as elites divergentes.

Por outro lado, a intenção do Imperador de extinguir aos poucos o regime escravista despertou a desilusão dos fazendeiros 
do Vale do Paraíba, por esperarem do mandatário uma atitude mais proativa aos interesses do café. Entretanto, “os barões fluminenses, únicos adversários frontais da medida, tinham-se tornado inexpressivos, em 1888, como força social". (FAUSTO, 2014, p. 133).

Para Fausto (2014), a perda da base social de apoio do Império é decisiva para a chegada da República. Esse novo modelo político institucional surge apoiado no crescimento do setor industrial, no fortalecimento da burguesia e no fim do trabalho escravo. Esses são, entre outros, o conjunto de fatores que mudam a composição e a percepção dos estratos sociais que compunham o novo regime.

É preciso observar que, apesar de serem estes os anos nos quais cresce a quantidade de pessoas remuneradas no Brasil, isso não foi acompanhado pelo aumento das vendas da publicação da Revista Illustrada. A queda nas vendas teve como consequência um aumento de preço, e a Revista já não era a mesma sem seu editor Angelo Agostini, como veremos mais adiante.

De qualquer modo, há evidências de que a Revista Illustrada foi parte do processo educacional inaugurado nos primeiros anos da República do Brasil, colaborando na divulgação e na consolidação dos novos hábitos e costumes que chegaram junto com o novo regime através de suas charges e quadrinhos. As fontes revelam, ainda, que o que era publicado na Revista possuía caráter educacional, divulgando novos parâmetros para a higiene da época, analisando reformas educacionais propostas, valorizando o surgimento de novas escolas, como a de engenharia, e destacando as figuras heroicas da República.

A primeira edição após a proclamação da República no Brasil é a de número 569, publicada em 16 de novembro de 1889 , décimo quarto ano de sua existência. 


\section{PROCLAMACÃO DA REPUBLICA NO BRAZIL}

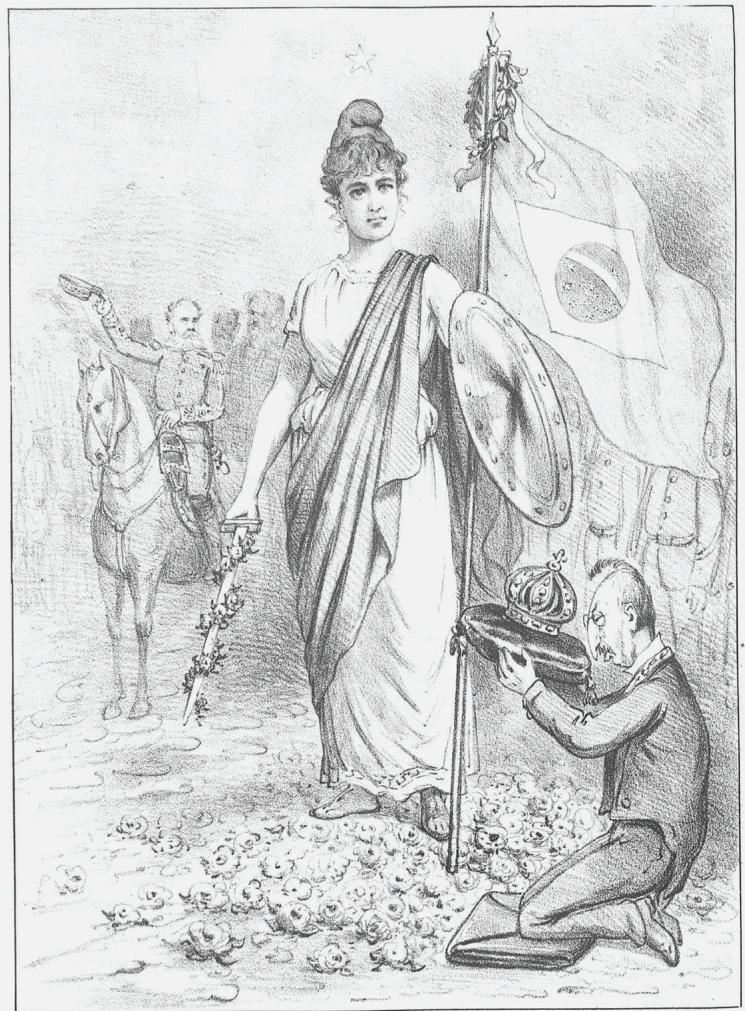

GLORIA Á PATRIA! HONRA AOS HEROES DO DIA 15 DE NOVEMKBRO DE 1889. HOMENAGEM DA "REVISTA ILLUSTRADA"

Contracapa da Revista Illustrada, edição nº 569, de 1889

Como se vê, a Revista prestou homenagem à chegada do novo regime, destacando que "foi proclamada a Republica Federal Brazileira, único regimen que convem à nossa patria e que havia de ser um facto mais hoje mais amanhã" (REVISTA ILLUSTRADA, 1889, edição 569, p. 2). A edição também ressalta a composição do Primeiro Ministério Republicano, com Dr. Ruy Barbosa, Ministro da Fazenda; Marechal Deodoro da Fonseca, Chefe do Governo 
Provisório; Quintino Bocayuva, Ministro das Relações Exteriores; Dr. Campos Salles, Ministro da Justiça, que posteriormente se tornaria o quarto presidente da República do Brasil.

$\mathrm{Na}$ edição seguinte, ou seja, a de número 570, a Revista destaca o modo como outras nações receberam a notícia da proclamação da República brasileira. "Nossa patria conquistou um renome immortal, e, hoje, em toda a parte, os filhos do Brazil são acariciados, e tornam-se alvos das homenagens dos povos civilisados, como pertencendo a uma raça de homens extraordinários" (REVISTA ILLUSTRADA, 1889, edição 570, p. 2). Assim, observam-se os elogios que a Revista faz em torno do povo brasileiro, bem como ao olhar dos considerados civilizados sobre o Brasil que, até então, vivia no obscurantismo.

A partir desse momento, passa a se tornar comum a divulgação de textos e ilustrações na ótica da defesa do novo regime e de uma nova maneira de educar, seja nos hábitos de saúde, na maneira de retratar os feitos do novo modo de governo ou na análise e na divulgação do que vai passando a mudar na educação com a chegada da República.

Todavia, a Revista Illustrada vai perdendo seu caráter contestador, marca de seu editor Angelo Agostini, chegando a um período de instabilidade editorial, no qual muda sua periodicidade de publicação semanal para esporádica. Tal fato é acompanhado pela queda do número de assinantes, período de sua decadência editorial. Nessa perspectiva, é preciso pensar na função social da arte, ou no papel que a Revista cumpria na contraposição do Império, porque "no momento em que o critério de autenticidade deixa de aplicar-se à produção artística, toda função social da arte se transforma. Em vez de fundar-se no ritual, ela passa a fundar-se em outra práxis: a política" (BENJAMIN, 1994, p. 171).

$\mathrm{O}$ autor faz aqui o debate no seu artigo A Obra de Arte na era de sua reprodutibilidade técnica, no qual nos mostra como a arte muda e onde se situa nos tempos contemporâneos, assim como o faz a Revista Illustrada na República brasileira. Tal fato que ocorre 
no Brasil, o do fortalecimento da burguesia e de uma sociedade burguesa, também acontece na Europa.

Essas mudanças são, para Elias (1994), elementos da estrutura social que foram alterados e, por vezes, isso vem acompanhado pela disseminação dos novos hábitos e costumes que, para os burgueses, eram os bons costumes, como podemos ver no debate que Srbek (2014) faz sobre esse tema relacionado às histórias em quadrinhos. Diz o autor: "no final do século XIX, difundiu-se a preocupação com a moralização e disseminação de 'bons costumes', levando a um considerável aumento da atenção dada à infância" (SRBEK, 2014, p. 26).

No caso do Brasil, a defesa dos novos bons costumes era feita pela imprensa da República, inclusive pela Revista Illustrada. Ocorre um fato curioso, as caricaturas que, até então, e em geral, eram marcadas por exagero passam a retratar o mais fidedignamente possível os expoentes da política republicana. A Revista passa a defender o regime, ao invés de fazer o que era comum nas charges e caricaturas até quase o fim do século XIX: criticar e ridicularizar os governos e costumes.

Para além da defesa da República, era grande a quantidade de assuntos que a publicação abordava: obituários, peças críticas de livros que eram publicados na época, ilustrações e muitos outros tipos de materiais que comunicavam com seu público. Dentre todos estes, fizemos a análise das ilustrações que abordavam questões vinculadas à educação ou que se propunham a educar, na perspectiva da civilidade e de um cotidiano republicano. 


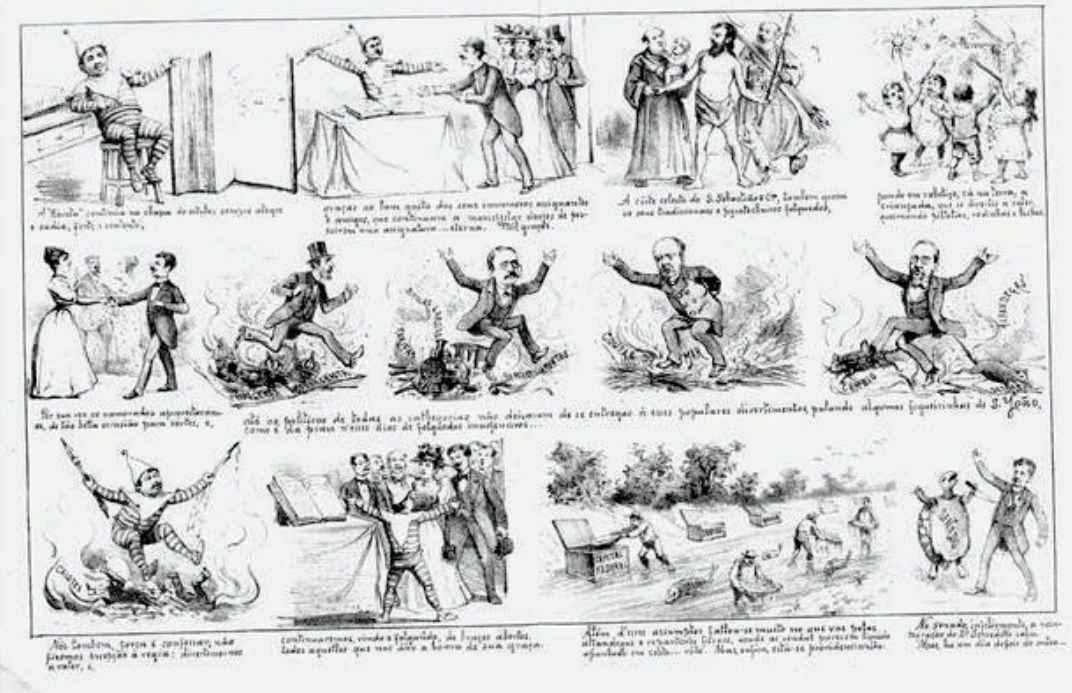

Revista Illustrada, edição $n^{0} 717$, de 1896

Os textos abaixo das ilustrações falam da alegria de vários personagens, inclusive do próprio bem estar da Revista que "continua na chapa do estylo: sempre alegre e sadia, forte e contente e [...] os namorados aproveitaram-se, de tão bela ocasião para sortes, e, até os políticos de todas as categorias [...]. Continuaremos rindo e folgando, de braços abertos, todos aquelles que nos dão a honra de sua graça" (REVISTA ILLUSTRADA, 1896, edição 717, p. 4). É provável que as ilustrações e os textos estivessem se referindo às festividades de junho, considerado um dos meses mais populares do Brasil, conforme podemos observar no último parágrafo da coluna central da página três dessa edição.

A Revista celebrava a cada dia a República no que tinha de mais interessante, os aspectos humanos e da sociabilidade. Em várias edições são destacadas as inúmeras atividades artísticas realizadas em clubes e salões, como apresentação de teatro e concertos musicais. Aliás, a Revista destaca esses momentos dos clubes e salões como um dos grandes benefícios da República, 
em que a população estava mais desinibida e feliz. "Entre as beneficas influencias que o regimen actual tem tido em nosso meio, nota se o desenvolvimento artistico" (REVISTA ILLUSTRADA, 1896, edição 717, p. 6). Não obstante os elogios à República, o texto dispara a crítica ao antigo regime. "A monarchia, apezar da classica erudição de D. Pedro II e das reuniões da serissima D. Isabel, medrava como a hera, numa população triste e concentrada" (Idem).

Desse modo, os textos acompanhavam o novo formato que viviam as histórias em quadrinhos e charges da Revista Illustrada. Eram apelos na defesa do novo regime e de seus símbolos somados a retratações de cenas do cotidiano da capital federal. Eles também haviam praticamente suprimido seu caráter contestador e aderido à defesa da República, uma clara demonstração que a Revista tinha uma linha editorial definida e fazia de maneira uníssona a defesa do novo regime.

Textos e imagens se imbricavam, agora, nos argumentos de que a nova situação brasileira deveria ainda ser aprendida e construída a partir dos benefícios sociais advindos da República. E era urgente perceber as mudanças da estrutura social que sustentava o novo regime. Por isso que a Revista insistia em dizer: A Republica não podia ter sahido de um jacto, perfeita e acabada, como Minerva da cabeça de Jupiter. [...] Hoje, decididamente, já as novas instituições funcionam sem attritos e com o elasterio suficiente para alentar todas as aspirações justas. (REVISTA ILLUSTRADA, 1896, edição 717, p. 2).

Vale destacar, além disso, que é nesse período histórico que surge a burguesia financeira brasileira. Há todo um embate em torno do referencial a ser seguido na época, como as alterações de costumes que vão se dando lentamente, e a República, por sua vez, vai mostrando o quanto ainda tem de Império e de conservadorismo nas práticas políticas e relações sociais, mesmo nos novos tempos. 


\section{Considerações finais}

É interessante notar que a Revista Illustrada nunca deixou de mesclar os temas do cotidiano na difusão do discurso em suas páginas, tanto nas ilustrações e histórias em quadrinhos quanto nos textos e poesias que publicou.

A Revista modelou opiniões contra o Império, ao mesmo tempo em que defendia a República, num momento em que o regime monárquico fazia parte de uma tradição rompida e os que defendiam o novo careciam da aceitação de seu discurso em parcelas mais expressivas da nova sociedade.

O discurso do nacionalismo, presente no fim do Império e vinculado à edificação da brasilidade, da República de nosso país, teve na imprensa um grande aliado. Foi ela que ajudou na desconstrução da tradição representada pelo regime monárquico e mobilizou os que detinham as razões, ou seja, a elite da época, na defesa do novo, mobilizou e foi mobilizada por esse estrato social.

A imprensa funcionou na difusão do discurso cumprindo o papel de intelligentsia que não pertencia a elite, mas tampouco era parte dos setores sociais que nasciam fruto da nova conjuntura com divisão social de trabalho, formação de classe operária e surgimento de uma classe média a ser disputada pelas novas concepções contidas no discurso da Revista Illustrada.

Por outro lado, obviamente, outros órgãos da imprensa se punham a serviço de construir uma nova opinião, divulgar uma nova referência a ser seguida e erguer, com o passar do tempo, uma nova tradição que viria a ser respeitada com o passar das gerações, com o intuito de fortalecer a República do Brasil.

\section{Referências}

AGOSTINI, Angelo. Revista Illustrada, edições 351 de 1883; 385, de 1884; 717, de 1896 e 569, de 1889 in: http://www. 
hemerotecadigital.com.br/acervo-digital/revista-illustrada/332747.

ANDRAUS, Gazy. As histórias em quadrinhos como informação imagética integrada ao ensino universitário. São Paulo: tese de doutorado defendida em 2006 na Escola de Comunicação e Artes da Universidade de São Paulo - USP

BENJAMIN, Walter. Obras escolhidas. São Paulo: Brasiliense, 1994. $1 \mathrm{v}$.

COSTA, Carlos. A revista no Brasil do século XIX: a história da formação das publicações, do leitor e da identidade do brasileiro. São Paulo: Alameda, 2012.

ELIAS, Norbert. O processo civilizador. Rio de Janeiro: Jorge Zahar Ed., 1994. $1 \mathrm{v}$.

FAUSTO, Boris. História concisa do Brasil. São Paulo: Edusp, 2014.

MARINGONI, Gilberto. Angelo Agostini: a imprensa ilustrada da corte à capital federal, 1864-1910. São Paulo: Editora Devir, 2011.

SRBEK, Wellington.Um mundo em quadrinhos. $2^{\text {a }}$ ed. João Pessoa: Marca de Fantasia, 2014.

TARDE, Gabriel. A opinião e as massas. São Paulo: Martins Fontes, 2005. 